\title{
John H. Gibbon, Jr., M.D.: surgical innovator, pioneer, and inspiration.
}

Jordan P. Bloom, B.S.

Thomas Jefferson University

Charles J. Yeo, MD

Thomas Jefferson University

Herbert E. Cohn, MD

Thomas Jefferson University

Pinckney J. Maxwell, IV, MD

Thomas Jefferson University

Follow this and additional works at: https://jdc.jefferson.edu/gibbonsocietyprofiles

Part of the History of Science, Technology, and Medicine Commons, and the Surgery Commons Let us know how access to this document benefits you

\section{Recommended Citation}

Bloom, B.S., Jordan P.; Yeo, MD, Charles J.; Cohn, MD, Herbert E.; and Maxwell, IV, MD, Pinckney J., "John H. Gibbon, Jr., M.D.: surgical innovator, pioneer, and inspiration." (2011). Department of Surgery Gibbon Society Historical Profiles. Paper 32.

https://jdc.jefferson.edu/gibbonsocietyprofiles/32

This Article is brought to you for free and open access by the Jefferson Digital Commons. The Jefferson Digital Commons is a service of Thomas Jefferson University's Center for Teaching and Learning (CTL). The Commons is a showcase for Jefferson books and journals, peer-reviewed scholarly publications, unique historical collections from the University archives, and teaching tools. The Jefferson Digital Commons allows researchers and interested readers anywhere in the world to learn about and keep up to date with Jefferson scholarship. This article has been accepted for inclusion in Department of Surgery Gibbon Society Historical Profiles by an authorized administrator of the Jefferson Digital Commons. For more information, please contact: JeffersonDigitalCommons@jefferson.edu. 


\title{
John H. Gibbon, Jr., M.D.: Surgical Innovator, Pioneer, and Inspiration
}

\author{
JORDAN P. BLOOM, B.S., CHARLES J. YEO, M.D., HERBERT E. COHN, M.D., \\ PINCKNEY J. MAXWELL IV, M.D.
}

From the Department of Surgery, Jefferson Medical College of Thomas Jefferson University,
Philadelphia, Pennsylvania

$\mathrm{T}$ hroughout history there have been many discoveries that have changed the world, including Albert Einstein's theory of relativity, Alexander Graham Bell's telephone, and Jack Kilby and Robert Noyce's microchip. There are a few analogous contributions that have been made in medicine: Sir Alexander's discovery of penicillin, Lister's principles of antiseptic technique, Salk and Sabin's vaccines for polio, as well as numerous others. These innovative thinkers all had two factors in common. First, they were pioneers who faced problems that had no solutions at the time and who refused to accept the status quo in the face of great scrutiny and resistance. Second, their contributions would forever change the world. In 1930, a profound experience with a patient would forever change Dr. John H. Gibbon, Jr. and stimulate an idea to create a device that at the time sounded audacious and impossible. His device would temporarily take the role of both the heart and lungs to make repairs inside the heart or the great vessels. Twentythree years later, Dr. Gibbon used his machine to perform the first successful bypass-assisted open heart surgery.

John Heysham Gibbon, Jr. was born on September 29, 1903 in Philadelphia, Pennsylvania to Marjorie Young and John H. Gibbon, Sr. Both parents were intellectuals, and they raised their son in an environment rich in stimulation, discipline, and commitment. They taught him how to write and play chess, talents he maintained and developed into a high level of mastery throughout his life. Gibbon attended prestigious schools in Philadelphia, the Episcopal Academy for grade school and the William Penn Charter School for secondary school. In 1919, he entered Princeton University where he studied Philosophy and Religion. In 1924, at the young age of 19, Gibbon graduated from Princeton, and following a family tradition, he enrolled in Jefferson Medical College in Philadelphia. Both John's

Address correspondence and reprint requests to Pinckney J. Maxwell IV, M.D., Assistant Professor of Surgery, Division of Colon and Rectal Surgery, Department of Surgery, Jefferson Medical College of Thomas Jefferson University, 1100 Walnut Street, Suite 500, Philadelphia, PA 19107. E-mail: Pinckney. Maxwell@jefferson.edu. grandfather, Robert Gibbon, and his father, John H. Gibbon, Sr., earned their medical degrees from Jefferson Medical College. After completion of his first year, Gibbon seriously considered quitting medical school to further pursue his passion in writing and poetry. His father eventually convinced him to stay in medical school. In the later years of medical school, Gibbon developed a fascination with physiology, which would become very important later in his career (Fig. $1^{1}$ ). After graduation in 1927, Dr. Gibbon went to Pennsylvania Hospital to complete a 2-year internship, where he was exposed to his first clinical research project. This experience prompted him to pursue a research fellowship at Harvard University under the guidance of Dr. Edward D. Churchill. Dr. Churchill was a prolific thoracic surgeon that was well versed in research. While working in the Churchill laboratory, Dr. Gibbon met a young intelligent research assistant, who would later become his wife, named Mary Hopkinson.

On Friday, October 3, 1930, while working in Boston, Dr. Churchill was asked to evaluate a 53-year-old woman who was 2 weeks postoperative after a cholecystectomy. The patient was complaining of pleuritic chest pain and quickly became tachycardic and dyspneic. Dr. Churchill made the diagnosis of a massive pulmonary embolism and immediately took the patient to the operating room for a pulmonary embolectomy, also known as the Trendelenburg operation. No one had ever survived such an operation in the United States, and there were only a few survivors in Europe. Dr. Gibbon was assigned to monitor the patient throughout the night. In his words, "My job that night was to take

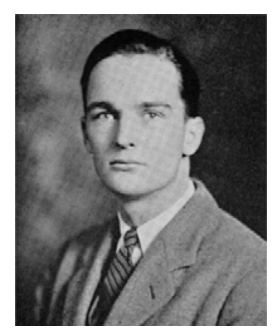

FIG. 1. Fourth year medical student, John H. Gibbon, Jr., 1927. 
the patient's blood pressure and pulse every 15 minutes and plot it on a chart." At 1:00 AM, the patient's condition acutely worsened and after another heroic bedside surgical attempt by Dr. Churchill, she died. This experience would provide the foundation for Dr. Gibbon to forever change medicine. In his words, "During the 17 hours by the patient's side, the thought constantly recurred that the patient's hazardous condition could be improved if some of the blue blood in the patient's distended veins could be continuously withdrawn into an apparatus where the blood could pick up oxygen and discharge carbon dioxide, and then pump this blood back into the patient's arteries. Such a procedure would also lend support to the patient's circulation while the embolectomy was being performed". ${ }^{2}$ Dr. Gibbon dedicated his life's goal from this point forward to create such a machine.

In 1931, Dr. Gibbon returned to Philadelphia and began practicing surgery at Pennsylvania Hospital. His mornings were typically dedicated to operating whereas his afternoons were spent working in the lab with his wife Mary. In 1934, Dr. Gibbon decided that his research could be better conducted at Harvard with Dr. Churchill, so he requested another research fellowship. He told Dr. Churchill that he was working on a device to provide extracorporeal circulation. Although Dr. Churchill was skeptical, he again welcomed Dr. and Mrs. Gibbon back to Boston. Despite many obstacles, Dr. Gibbon was able to successfully use the first heartlung circuit in a cat. During one experiment, he perfused a cat for 2 hours and 51 minutes with the pulmonary artery clamped. ${ }^{3,4}$ After Dr. Gibbon completed this second research fellowship, he again returned to Philadelphia to take a position as the Harrison Surgical Research Fellow at the University of Pennsylvania. He continued to pursue his research utilizing artificial circulation, maintaining long term survival in cats.

In January of 1942, during World War II, Dr. Gibbon volunteered for active military duty and was deployed to the South Pacific. After 4 years of duty, Dr. Gibbon was discharged from the Army in 1946 as a Lieutenant Colonel (Fig. $2^{1}$ ). Upon returning to Philadelphia, he accepted the position of CoChairman of the Department of Surgery, Professor of Surgery, and Director of Surgical Research at Jefferson Medical College. He also resumed working on his heart-lung machine. His two greatest barriers at this point were the sophisticated engineering and finances required. A medical student named E.J. Clark had an idea to help solve these problems. Using a family relationship, he arranged a meeting between Dr. Gibbon and Thomas J. Watson, Sr. who was the Chairman of IBM. Watson immediately offered the assistance of his company, assigning one of his top engineers to the project. Dr. Gibbon also expanded his clinical work force with the addition of numerous surgical residents including:
Bernard J. Miller, M.D.; Frank F. Allbritten, Jr., M.D.; Thomas F. Nealon, Jr., M.D.; and John Y. Templeton, M.D. In 1952, with great progress in animal experimentation and technology, Dr. Gibbon felt it was time to use his device on a human. In February of 1952, Dr. Gibbon and his team operated on a 15-month-old female with a clinical diagnosis of an atrial septal defect. After the patient was placed on bypass, the heart was opened and no defect was appreciated. The patient subsequently died in the operating room, and an autopsy later revealed that she had a patent ductus arteriosus. This experience illustrated the additional need for more advanced preoperative diagnostic tools. Cardiac catheterization was only in its infancy, but Dr. Gibbon sent one of his best residents, Dr. Robert G. Johnson, M.D. to learn the technique. ${ }^{5}$ On May 6, 1953, Dr. Gibbon performed the first successful operation using the extracorporeal circuit to repair an

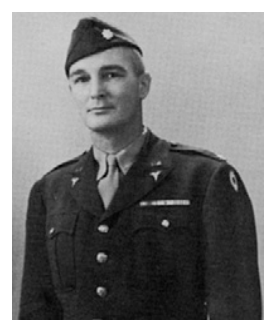

FIG. 2. Lt. Col. John H. Gibbon, Jr., circa 1944.

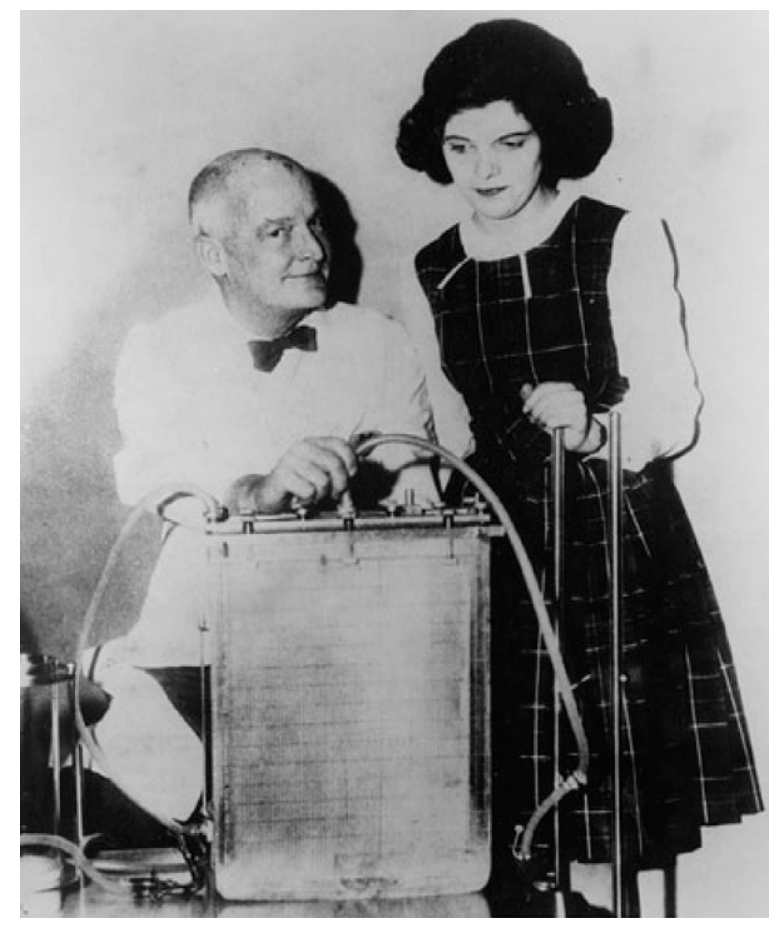

FIG. 3. Dr. Gibbon and former patient Cecelia Bavolek pose before the Plexiglas-covered "lung" 10 years after the landmark operation, 1963. 
atrial septal defect in an 18-year-old college student named Cecelia Bavolek (Fig. $3^{1}$ ). Dr. Gibbon was well known to be vehemently opposed to personal publicity, so the first and only report of the operation was published in the Minnesota Medical Journal almost an entire year later. After the successful operation, Dr. Gibbon only attempted two more procedures with his heart-lung machine. Both resulted in the death of the patients, and he deemed the technique too premature to be used safely. He never again operated on the heart.

In 1956, Dr. Gibbon became the third Samuel D. Gross Professor and Chair of the Department of Surgery at Jefferson Medical College, a position he held until retirement in 1967. After he retired from medicine he completely detached from all things medical and focused on his other passions in life including spending time with his family, playing tennis and chess, and writing poetry. Over the course of his career, Dr. Gibbon was a member of 33 medical societies and the president of six, including the American Association of Thoracic Surgery, the American Surgical Association, and the Society of University Surgeons. He held four honorary degrees and authored 125 clinical and research publications. He was a long-time editor of the Annals of Surgery and the editor of the Surgery of the Chest textbook in 1962. He received 11 awards, including the prestigious American Heart Association's Research Achievement Award in 1965 and the
Albert Lasker Clinical Research Award in 1968 for his work on the heart-lung machine. Sadly, he did not receive a richly deserved Nobel Prize for his contributions. ${ }^{6}$ On February 5, 1973, Dr. John H. Gibbon, Jr. suffered a fatal myocardial infarction at the age of 69 while playing tennis at his home in Media, Pennsylvania with his wife Mary. His legacy lives on at his alma mater, the Jefferson Medical College, with two important entities: the John H. Gibbon, Jr. Surgical Society, a surgery interest group, and the annual John H. Gibbon, Jr. lecture.

\section{REFERENCES}

1. Dr. John H. Gibbon, Jr. and Jefferson's Heart-Lung Machine. University Archives and Special Collections. Available at: http:// jeffline.jefferson.edu/SML/Archives/Highlights/Gibbon/gibbon2.html. Accessed April, 12, 2011.

2. Gibbon JH Jr. The gestation and birth of an idea. Phila Med 1963;59:913-6.

3. Gibbon JH Jr. Artificial maintenance of circulation during experimental occlusion of pulmonary artery. Arch Surg 1937;34: 1105-31.

4. Gibbon JH Jr. The maintenance of life during experimental occlusion of the pulmonary artery followed by survival. Surg Gynecol Obstet 1939;9:602-14.

5. Roses DF. Profile: John H. Gibbon, Jr., M.D. Traditions in Surgery 1995;2:2-12.

6. Pastuszko P, Edie RN. John H. Gibbon, Jr., the inventor of the first successful heart-lung machine. J Card Surg 2004;19:65-73. 